\title{
Corruption, Corruptive Influence and Social Change in Nigeria
}

\author{
Longe, Joshua Sunday \\ Department of Sociology and Anthropology \\ Faculty of Social Sciences \\ University of Benin, Benin City \\ Edo State, Nigeria
}

\begin{abstract}
The proverbial cultural particularism of hard work, diligence, good family name of Nigerian urbanites seems to have failed in promoting social order in modern Nigeria. Ab initio, strong family values, noble endeavours and diligence were assumed to provide plausible reputation for individuals as they venture into new careers in the society. In contemporary Nigeria, cultural and family values, integrity and honesty have failed. Taking a historical perspective; in Nigeria, development is traceable to indigenous growth that hinge on strong family ties, ethnic and cultural values which provide impetus necessary for socio-economic relationships before imperialism. The functionalism of the early period gave way to the anomaly that characterizes the modern era of exogenous and endogenous social change. Composite cultural and family values have been replaced by barefaced wanton crave for wealth, fame and economicpower in present Nigeria. This paper attempts to explain the 'how' of corruption, it subsistence nature and consequence for social change in Nigeria today. The contemporary sociological theory bears responsibility of adequacy to explain the change in Nigeria. For example, the "middle range" theory of crime and corruption appears to be a theory of cause and effect. This tendency of causal relationship is predictable and addresses futuristic realisms. It is suggested that Nigeria faux pas is a function of the failure of erstwhile esteemed socio-cultural values in the country. The paper suggest ... is there alternative way forward?
\end{abstract}

Keywords: Corruption, Contemporary Nigeria, Family values, Social Change.

\section{Introduction}

The nexus between corruption and social change in Nigeria is historical. Social values, change and development are somewhat interwoven and mutually inclusive that one cannot discuss one without the other. The sweeping change that greeted independent Nigeria is a combine influence of colonialism (imperialism) and information technology (Mustapha, 2000; Crowder, 1962). It occurred together as a problematic aspiration unmatched in previous times in Nigerian history. Human societies adopt values considered germane to their development and these values become engines that drive change and inform the consciousness of individuals within it (Osaghae \& Suberu, 2005).This, orientates, directs and guides a people's line of actions and social conduct till exogenous or endogenous forces arise to further provoke requisite changes.

It is very contentious though, whether or not the mutuality of social currents (values) has always been genial, bolstering and regenerative. If social values provoke the existence of a certain mode of social change and development which creates ideological divide in Nigerian society; has corruption then become inevitable, given that it is a kind of social value? The debate is quite engaging. This paper attempts to explain the 'how' of corruption, it subsistence nature and consequence for social change in Nigeria today. Corruption is a behaviour that deviates from proper responsibilities of a public role as a result of private-regarding (personal, private clique, close family ties) pecuniary or status gains; or that behaviour which violates the rules to exercise certain private regarding influence (Nye, 1967).Corruption destroys social life, legitimacy and attack the very fiber of the human society (the family) on which confidence should rest (Stefan, 2018).

Corruption in Nigeria is an 'assurance problem'. An assurance problem exists when all actors are better off if they remain on the same minimum standard of livelihood, but are second best off if, a social actor defects from continuing to remain on minimal standard of living to join those who already defected. A social actor is worst off if, they defect but did not share ideals of those who have defected (Nicholas, 2004). Social actors faced with assurance problem, therefore, must choose between cooperating in hopes of accruing great benefits for defecting or suffer defensive measures. For instance, Jigbale (2016) indicates that the prevalence of corruption in Nigeria today is a thing of 'value' which the potency of social institution is failing to correct. African Development Bank (2014) and Freedom House (2012) perceive that the Nigeria society over the years has grappled with the issue of unemployment, income inequality and monolithic dependency on oil. 
The period of economic growth as a result of oil exportation that generates $77 \%$ of total government revenue has not benefitted the poor, reduced poverty or obliterated social depravity and has resulted in misappropriation of government funds among others. It is verified with critical opinion that this occurrence is traceable to corrupt power-elites regarded as chieftains of mis-management and the causes of Nigeria's underdevelopment (Global Witness, 2012).

However, one should not pander to popular tendency to see corruption as existing in customary remoteness, because not only is corruption pathologically penetrative and infectious, it is an issue in social change and development (Kathleen, 2003). War against it is never ending and seemingly never won. For instance, Sociologists (Wallerstein, 2007; Dahrendorf, 1968) hold a deep mistrust for the role of 'value' in human relations and operation of social, political and economic activities which cannot be dismissed as a failure on their part to reconcile with the inevitable. For without a doubt, value has been associated with the least desirable of social facts. If value is the engine of human action and behaviour, it is plausible also that it is the locus of corruption and 'sharp' practices in the society as we know it today. Similarly, social virtues and vices, conduct and interaction, riotous demonstration, ethnic discrimination and religious bigotry and problems are almost exclusive to human values. In addition is the fact that value gives rise to focus and determination which is a characteristic that portrays modern Nigeria from culture to counter-culture, one ethnic nation to another and from public to private sphere (Erdmann \& Engel, 2007). The rest of the paper is divided into three sub-sections. Sub-section one about the historiography of pre-Nigerian society and the Westernization of indigenous values, Section two is on the resultant transformation and effect of culture contact. Section three is a theoretical synthesis.

\section{Section One}

\section{Pre-Nigerian Society and Nigerian Families}

Assessment of the Nigerian society often takes a Western coloration that portrays the society after the erstwhile colonial influence. Nigeria pre-historically is described as autonomous society comprising different regions ruled by kings. The Nok in central Nigeria, the Hausa/Kanem Bornu-Fulani Empire dominating the North, and the Yoruba entity of Ile Ife and Oyo in the Southwest was equally prominent while the Nri Igbo kingdom thrived in the East (Crowder, 1962; Osaghae, \& Suberu, 2005). Before the advent of colonial hegemony and suzerainty of imperialism, the preNigerian states were mainly administration of empires and kingdoms. Indigenous Nigeria was a place where commerce created wealth and people, town and settlements developed in response to trade. Small scale subsistence agriculture dominated the reins of socio-economic relationship. Economic production was centred on the family with minimal storage and under-developed mode of transportation. Majority of people were peasant farmers, boat builders, traders in ivories such as tortoise shell, rhinoceros horn, skin and hide, wool fabric among others (Okolocha, 2014). However, this social economic clientele was to decline as focus on economic activities shifted from agricultural vocation to western dominated mode of production-the factory system (Okolocha, 2014).

A unique characteristic of pre-Nigerian society was its subsistence economy, social differentiation and self-generative mechanism. It was a necessary condition for social continuity and survival of family guild, recruits and inter-group apprentices (Okolocha, 2009). Societies were war-like and conquered territories were harnessed to extend rule and administration and dominant mode of exchange was the barter system (Okolocha, 2009). In 1914, the Niger areas were effectively brought under colonial rule and divided into two distinct regions-the North and the South for colonial administrative purposes. At this time, individuals were treated according to their ethnic disposition and thus by their families of origin in-order to maintain family legacy and to differentiate free-born from slaves (Falola, \& Heaton, 2008). The legacy of the family creates balance for individuals in the society traceable to their ethnic incline. Thus, family name, values and integrity become individual identity in the larger society. Extending from gulf of Guinea northwards, Nigeria occupies a land area of 923,768 square km. From the mountain and savannah of the north, Nigeria's veritable landscape slopes to coastal, swampy and tropical rain forest belt that balances hot, humid and rainy climate of the natives (Pratten, 2007).

The cultural diversity of the country is characterized by its variability, cultural multiplicity and ethnic plurality (Akanle, 2012). According to Otite (2002), there are over 300 ethnic groups in Nigeria, resulting in multiple cultures and language imprints which natives bear as part of them. Cultural ideology gauged general communications, approaches to development and mutual benefits in social relations (Otite, 2002).In indigenous Nigeria, cultural philosophy embodies shared ethnic and family values such as hard-work, respect for elders, regard for the age grade system and communal effort that is seen as antidote for poverty and engine of societal development (Akanle, 2012). In contemporary times, globalization propelled changes malleable to western features. This change seemingly now controls the 'will' of cultures, families and individuals in Nigeria today (see, Yakubu, 2014). Cultures in Nigerian society that served as spiritual, material and social aesthetic to rally support for order among families and individuals is yielding to imposing force of Western cultural-imperialism (values). 
For example, cultural heritage in the families and society such as marriage consummation in which the virginity of new brides were put to test and parents hide their faces in shame if their daughters were found non-virgin during wed-lock is fast declining. The moral basis for justification and acquisition of material wealth appeared dilapidated. Bribery, rape, semi-nudity, gangsterism, corruption, drug-addiction and arm-robbery et cetera is replacing cultural values of morality, confidence in noble family names and ethnic incline. The mass-media is taking over the role of family in socializing children and popular culture appears to have taking over the consciousness of most young people in the society. The proliferations of uncensored movies, get-rich-quick-syndrome and patronage of foreign product have negative effect on the cultural health of traditional Nigerian society with the family worst battered by it. Social order is threatened in cosmopolitan Nigerian society because the society today is fast shifting from collective to individualistic dynamics of family structure. The concept of respect for elders and extended family members is in constant feud with exogenous forces while most family moral principles is fast wearing away (Yakubu, 2014; Okolocha, 2014).

According to Olutayo and Akanle (2007), traditional division of labour within families associated with advantage of socialization is exchanged for predictability, rationality and efficiency which are indispensable affiliates of modernization. This interrogates the reason our society is grappling with corruption, underdevelopment and socioeconomic backwardness. The implication here is that modernity (global cultural force) produced dialectic that moderate our cultural values to the deepening divergence and corroding of the family as an effective institution in maintaining social order in Nigeria today. Reinforcing this dilemma is the protracted issue of corruption.

Social scientists conclude that the family is an agent of socialization upon which the survival of the society largely depends (Olutayo \& Akanle, 2007). This position puts the family in the lead for cultural responsibility and human development. The family represents the epi-center of humanity, the locus of change and expansion of human society and a link between the past and the future. The family is a bio-social institution that interacts with and influence individual behaviour in a more intimate pattern. The dynamic and functional nature of the family puts it at a very important capacity that fuses culture and societal stability together. A strapping link therefore exists between individual life experiences and the family he or she hails from. Thus people are perceived and judged by their background (family name and integrity) (Otite, Ogionwon, 2006; Ekong, 2003). The tangibility of material wealth is seen as a product of good family name and hard-work, among others virtues. The relative factor therefore is that one cherishes the continuity of family legacy above material wealth or possession in the society. This is the gift, ability and capacity that individuals have to chart their ways to success and demonstrate courage in the face of daunting challenges. This creates opportunities by which growths are determined and developmental pathways are valued and charted (Akanle, 2012; Oginwon, 2006).

The indigenous Nigerian family by global comparison has its own philosophies, value system and cultural ideals that serve as integrating and stabilizing force used to galvanize its growth and development in early times. In the context of traditional Nigerian belief, human dignity, honour and respect, hard-work and diligence, good family name and integrity hold prime place in the ideology of indigenous families and relationships as well as social engagement are establish on this basis. Olutayo and Akanle (2007) viewed that among Nigerian families, values for hard-work, chastity, loyalty, truthfulness, dignity, respect for authority, reliability support for others are etcetera are sublime social fact that are robustly well-established in the primordial institution and enforced through the family. Integrity and good family name serve as the basis for social and economic performance of individuals, especially in larger social setting. It is against this that people are considered eligible and allowed a place to engage in the domain of meaningful organizational and socio-cultural functions in the common interest of all. Threats and potentials are perceived by a long trajectory of generational family name and performance. This is more like a criterion that precedes an individual in Nigerian society before 'modern' time.

The communal nature and ethos of the indigenous Nigerian family gave rise to the impetus that facilitated social and economic development in the country before the advent of imperialism. Social diversity is considerably harnessed through the family as the locus of cultural embodiment could not be underestimated even in traditional forms (Akanle, 2009). Unfortunately, this once esteemed engine of socio-economic change and development seem to be losing its grip to the collectivities of force engaging it. The tightly packed power of culture (family ties and values) seems weak in the face of un-native exogenous influence that leaves it susceptible to virulent change and deploys alteration that translates to individualism rather than collectivism (Vaughan, 2005; Olutayo and Omobowale, 2005).

\section{Westernization of Family Values in Nigeria}

World-over, the influence of family value can neither be under estimated nor overemphasized. Values are integral component of culture that tends to pilot human affairs. It determines attitude, rationality and standard for what is acceptable and beneficial. It reflects the supremacy of a family as organic entity to dictate social currents relatively of high density in society (Asogwa, 2008; Chuta, 2006). 
As a result of limited socio-economic differentiation, families were homogenous and social-organic solidarity among them was very strong. Therefore, individualism (mechanical solidarity) associated with western-imperialism did not exist (Okolocha, 2009).Family value crystallizes into convictions that manifests on the outward in peoples' behaviours. This suspicion characterizes the society, thus the peculiarity in patterns of life and lifestyle of people. Family values are hard to peel because they constitute the socio-cultural fabric of human development. Its breakdown could result in anarchical and commercialized society where corruption, deviance and any form of social vices occur. If values represent a people, then it can be said that 'Westernization' was never a native value-system of Nigerian as a people (Odinye and Odinye, 2012; Bordo, 2004; see Achebe, 1958, 1984).

Western values such as capitalism, democracy, money economy, information technology; globalization among others, reflect a sharp contrast to Nigerian value system. While it has provoked positive changes, it has also set the milestone for several negative changes in Nigerian society today Osaghae, and Suberu, (2005). Corruption, internet fraud, white collar crimes, homosexuality, lesbianism, economic and political imperialism and the mandatory English language as lingua franca, among others, are perceived as negative yoke of western values. For instance, capitalism is not native to Nigeria but has been, by and large, accepted as a value system that today unsettles most Nigerian families. Capitalism creates alienation, encourages individualism and exploitation which exacerbates poverty and causes people to develop criminal tendency in-order to satisfy their needs (Hall, 2018; Blau, \& Blau, 1982). It promotes wanton crave for material wealth. This is evident in the way people be-labour themselves to breaking point in order to earn a living, prevalence of ritual killing for money ritual purposes, political office holders looting national treasury, and those who took to internet to scam unassuming victims (Madukwe \& Maduwe, 2010; Ezeanya, 2009; Egbeke, 2000).

'Western values' was traditional to colonialism-the harbinger of monetized economy and further entrenched by western-education and globalization to the supplanting of local cultural and family values in Nigeria. This created a social current which destroyed the cultural nerves of family values in the Nigerian society as we know it. Nigerian family values were effectively eroded by western religion and education that taught entirely different philosophies about human existence, production of agro-commodities and relegated local values and cultural beliefs as backward and barbaric (Watts, 2008; Havinden and Meredith, 2002). This ideological influence is a spectacle observable in government, schools, religion, the legal system and in everyday living of several Nigerians today (Smith, 2010). From marriage types to dressing patterns that reveal sensitive parts, infidelity that breaks happy homes, divorce that end promising marriages to wanton crave for material wealth and corruptions that cause calamitous compromise among individuals and those trusted with state affairs. The list appears endless of the negative impact of western values in Nigeria.

\section{Family Values and Corruptive Influence}

In Nigeria, the structural role of the family represents duality of socialization and assimilation. It is a principle which presupposes responsibility and equality for all. Integral life, social, and material provision are on this communal basis. Members of family were cared for respectfully and responsibly (Maduke \& Madukwe, 2010). Everybody was connected one with another through a complex social network of extended and immediate living and dead family relationship. The family was considered as concentric circle that extended outwards forming chain of extended families, village, clan and ethnic groups (Egbeke, 2000). The family confers identity, cherish esteem and give worth to things. In the traditional setting, a person is an individual to the extent that he belongs to a family (Ogbonmwan, 2008).Family values are rare gems treasured very highly with regards to cultural philosophy of satisfaction and contentment. Deviation from it was considered as treachery and attracts severe sanctions

The incursion of European powers into Nigeria society in the sixteenth century typifies an exogenous influence that marked the beginning of syncretism and unending change in values and social-identity. The incursion was triggered by economic need of the over-lords to acquire natural resources such as cocoa, rubber, oil palm, tea, cotton, cane sugar, groundnut, maize among others to feed their burgeoning industries (Okolocha, 2014). This colonial action prompted a new type of commodity exportation. Although, socio-economic exploitation of material resources commenced immediately, the mutuality to harmonized values and culture never existed, rather the domineering force of the overlords created changes with domino-effect on every aspect of the society that today continue to reverberate in the postcolonial Nigeria. Colonialism never undertook the tedium of integrating local values into western ones; rather, it created a system that destroyed it (Gottdeiner \& Hutchinson, 2006; Garba. 2003). The disarticulation engendered social dis-organization in peasant Nigerian society and signalled a new dimension of 'craving' and pattern of consumption among its populace. Colonialism monetized the economic system. This was hitherto never experienced in the country before. This change caused a reverberative up-turn in the socio-economic experience of peasant Nigerian society. As a result, money became the value and the measure of everything. 
Intensive economic development to meet exportation demands created developmental antithesis that 'broke family will and values' and shifted responsibility to budding local industries and a western way of life. It created the jurisdiction between the poor and the rich and if there was ever such a concept as 'poverty' and 'stratification' in pre-colonial Nigeria, it very well exacerbates it. Thus, individuals strived to own large farmlands and large production of raw material for exportation. Trade with the overlord and agro-cultural activity became the basis for social security, wealth creation, social mobility and recognition. Money became the symbol of social status and means of social superiority (Madukwe \& Madukwe, 2010). This phenomenon created and facilitated the necessary conditions for the inevitable corruption in Nigerian society.

\section{Section Two}

\section{Corruption and Corruptive Influence: The other side of the Coin}

Widespread interest for socio-economic development has stimulated growing awareness of the consequence of corruption. Social scientists emphasize its presence in politics; philosophers emphasize it in the state and the contemporary man sees it as the effort to secure wealth and acquire power through dishonest means - private gain at public expense (Smith, 2010; Smith, 2001; Heidenheimer, 1978) Scholars maintain the opinion that corruption is pervasive and transmissible, and possesses socio-economically damaging effects to human society. They argue that most suffer at the expense of incompetent few (Okolocha, Longe and Alenkhe, 2013; Longe, 2015, Victor, 2014).Consequently, comparative performance facilitates assessment of the influence of corruption at individual and group level and stimulates untrue representation of cultural and family values.

The unformulated fragility of 'human mind', which psychologist believes can be conditioned with indispensable socioeconomic rewards often predispose individuals to material and economic benefits. Lust exemplifies endogenous influence that is characteristic of unbridled feelings of wantonness, craves, unguarded desires, indiscriminate aspirations and deliberate blindness to consequence of action in order to satisfy self-gratification. Lust is the corruptiveness of corruption that causes individuals to use collective means or exploit others to achieve often personal and surreptitious objectives. Usually, general interests are compromised as a result of lust. Corruptive influence is socially determined. It affects status; pattern of interaction and relationships among people in the society and also poses myriad of modern problems in organization and as well as families. It subsumes a situation where monopoly exits to the exclusion of discretion, commitment and accountability (Akanbi, 2007; Babawale and Onuah, 2007). Corruptive influence connotes situations in which individuals (bourgeoisie and those in government, etcetera) foster their 'will' upon people to take undue advantage of them. This pattern of social relations underscores corrupt behaviour. From such background, individual persons tend to be retaliatory and thus perpetrates it continuity. Seemingly, such behaviour appears to be engaging most 'mind' in Nigeria today.

The omnipresence of economic-survival and socio-psychological needs with the persistent character of human biosocial contraption reducible to human nature and activity tend to encourage subliminal decisions when opportunity seemingly present itself. Unwholesome acts that violate socio-cultural codes, usurping of various social relationships, dishonest conduct while rendering services and misuse of trusted privileges are behavioural pattern expressed by most people everyday, everywhere in society. In Nigeria today, corruptive influence is akin to cancer, a snow gathering mass as it continually rolls. It is the bane of legitimacy, democratic stability, socio-economic and political development. Endeavour by administrators to check this behavior has been unsuccessful and with the advantage of knowledge of the past, most Nigerian leaders with all intent and purpose to serve their father land as 'social physicians' have at one point or the other, departed the office as 'social patient' (Okereke, 2015; Okojie, 2012; Ogundiya, 2001).

\section{Social Change in Nigeria}

Economic production and transportation was metropolitan centred and imperative to new business elite, thereby provoking a new wave of out-migration from rural settlement to urban centres in search for money and new life. A significant consequence of the new economy was the introduction of money (cash) and taxation. Cash cropping was popularized and money increasingly became the main requirement to acquire consumer goods and pay tax. Indeed, it is a must have for one to be relevant in the new scheme of things. In order to survive, migrants became desperate for money and material wealth. Resultantly, it led to the jettison of highly esteemed values (good family names, hard-work, honesty and integrity) leading to variant of cultural dislocation in the society. The society began witnessing a surge in crimes and criminal activities one of which is corruption. This structural change became the social composition of the Nigerian society and of human relations within it that continues to produce social vices rife in government and among the populace today (Okolocha, 2014; Okolocha, 2009). 
The new economy is European hegemony to control Nigerian society. Its impact created a dislocation in local traditional culture and economy. Traditional authorities domiciled in Kingdoms and Empires lost power and cultural values lost its significance as social stratification changed forever. The family hegemony collapsed and individualism gained the ascendancy of communal identity. As a result of new economic power, Monarch, princes and indigenous administration transited into ordinariness from which they were never to recover their status. The impact of the new economy introduced by Europeans sounded the death of local traditional order in Nigeria as indigenous institution was cast asunder by colonial administration. Artisans, huntsmen and farmers lost their status in the modernizing order. The organization of craftsmen collapsed, forming an army of persons joining the out-migration stream in the new economy (Iwara, 2015; Ibhawoh, 2002).

Across the country were emerging new consumer goods, administrative patterns and social order besides the drain of able bodied individuals away from the country side. Local cottage system was effectively destroyed and local boundaries were blurred. Independent economies became satellites to dominant European economic powers. As a result, unemployment and family poverty, a phenomenon that never existed in traditional Nigeria was introduced. Thus, the society was set in continuous spiral.

The pursuit of personal enrichment without consideration for what is acceptable encourages citizens to engage in corrupt behaviour leaving the family and its values in exclusionary division. One of the reasons for this is that mostly individuals, not families go to urban centres to seek new climes. Therefore, socio-spatial structure created social morphology between individuals and their families-a phenomenon that today lives with us. The quest for material possessions, fame and social influence/recognition in the society has led to an increase in social vices and crime: corruption, political assassination, armed robbery, ransom kidnapping, materialism, thuggery and various forms of malpractices developing in its wake.

The society became 'heteropolise', with a diverse blend of ethnic groups, economic activities and lifestyles. The heterogenic nature of the society means that no common value exists and money tends to become the measure of all things. Formal control replaced informal control and it became necessary to adhere to predictable routines (Vago, 1999; Jencks, 1996). Individuals developed characteristic personality attributes and attitudes. They became secularized and free from family and cultural ties as a result of the mobility and diversity in the new economy (Akanle, 2009). Thus, corruption germinated out of the dislocation between individuals and families, between people and government and the crave for material wealth which today seems to have deeply woven into the socio-cultural fabric of Nigerians and appear to come naturally with the platform (colonial-monetarization and commodification of the economy, social services and relationship) that provoked it. Parents now encourage and teach children to be corrupt while lecturers take undue advantage of students vice versa (Omonijo, Uche, Rotimi, \& Nwadiolor, 2013; Ndubueze, 2011). The gospel of prosperity by some pastors' lead church members to commit untold crimes, law enforcement agents demand bribes to perform their duties, elders who should be custodian of virtues and truth in the society teaches youths to be violent and become successful political clientelism as passage to public office. Inasmuch as this social phenomena were large scale social changes in themselves, they are also social incidents that provoke other forms of incremental changes, resulting in less social control and poor public service delivery (Fritz \& Menochal, 2007; Smith, 2010; Smith, 2001; Erdmann \& Engels, 2006).

Many forms of corruption identified in the country today are traceable to the character of western social values and norms that sub-planted tradition value system and implicate certain changes in the society. Neo-patrimonialism for instance, negates the validity of transparency, accountability and true democracy. The trajectory creates a dysfunctional value system that affects vertical and horizontal modes of social relationships and gives rise to patron-client arrangements based on powerful individuals and groups. Corruption is everywhere, on the street, next door, in the church, in the mosque, in the market, department store, the police station and the police on beat patrol and the soldier at the check point (Chuta, 2004).

Nigeria is often included in the major international corruption appraisal, including Transparency International's Corruption Perception Index, Global Corruption Barometer, Bank Worldwide Governance Indicators and World Bank Business Survey; and has remained on an alarmingly at all time high over the past year as one of the most corrupt countries in the world (Transparency International, 2014; World Bank, 2007; Afrobarometer, 2013). From anticipation to get material wealth in cash or kind to the deliberate distortion of the truth;the interest is contagious as a deadly malady. Okadigbo (1987) believe that instances of corruption are everywhere in Nigeria. The essential existence of the pre-Nigeria society that suggests 'for one to be is to be with family, family values, clan and kinship' is no longer tenable in the face of sweeping socio-economic change. Consequently in Nigerian society today, 'to be' is to be materially wealthy and have money as much as possible (Egbeke, 2000). One may argue that pre-Nigeria tradition is primordial and should be rid of in the light of intellectual advancement and development of the West, but the dynamic nature of local family values help to sift wheat from chaff and regulate social order. 
Values that stand as regulator of behaviour in pre-Nigerian society now stand pale in the light of the social change (modernization) brought by the imperial West with attending socio-cultural and economic woes that Nigeria, its people and cultural heritage might never recover from.

The functionalism embedded in rural communities of the early period has given way to the anomaly that characterizes the modern era of exogenous and endogenous social change marked by functional independency. Nigeria has turned a neo-liberal state pursuing neo-liberal agenda which has not eliminated her from being a corrupt society; and the corruptiveness is becoming widespread more than at any other moment in history. It appears that corruption in Nigeria has acquired some form of immunity that networks itself through unbridled crave for economic power and material wealth among the citizenry and judged to be the heart of social interaction (Ko \& Samajdar, 2010).

The existence of traditional lifestyle and families (culture and ethnic groups) in modern Nigerian society today is perhaps to cushion the effect of the shock introduced by colonial rule. By accepting expanding economic opportunity, industrialization, globalization agenda, integrating 'modernization' and adopting information technology the experience of corruption will continue to engage our minds, and force a union between traditional and modernity in which the former becomes the effect of the latter.

\section{Section Three}

\section{A Synthesis of Theory}

The socio-cultural disorganization of local family and cultural values in Nigeria resulting from corruption-new economy introduced by colonial lords is a manifestation of culture-contact. To this end, family values, cultures and ethnic nationalities carries a tincture of western value system beyond their reconciliatory capacities. Thus corruption is not a reductionist concept as it is not people or nation specific (Ahmed \& Ullah, 2014; Lipset \& Lenz, 2000).

While the Europeans already have monetary system of exchange as different from barter system in pre-colonial Nigerian society and industrial system lacking in raw material for production that forces different expeditions into new lands and world coasts, pre-colonial Nigerian society was centred around family units and ethnic groups which serve to coordinate, regulate and control mode of life and social function. The demand for labour was minimal, life was simple, and economic supplies were surplus and provision reached everyone. No destitute persons roamed the streets in precolonial Nigerian society because the family, extended family, clans and villages took adequate care of all. Unemployment or family poverty as a socio-cultural condition or phenomenon never existed. Life was normal in local communities and among members of families; there was contentment and corruption as known today did not exist (Achebe, 1958; 1984).

Corruption arguably came with Western colonial influence and is thus a function of 'cravings' or desires for consumer goods and mode of economic exchange that confer social dignity, identity, status and position upon individuals not as a result of family name or societal background, but according to socio-economic power and position. These 'cravings' in different ways causes people to behave in unimaginable ways. Therefore, taxation, corruption, poverty and unemployment in modern Nigeria described as ills of capitalism were introduced by colonialism in the country. The colonial order dislocated traditional economy and individuals became attracted to the life experiences presented them by western ideals in -monetization and commodification of social relationships. Socio-cultural change became determined by these economic forces, therefore, the apparent existence of corrupt behaviour and social instability in the country.

If we subject corruption and social change in Nigeria to a sociological catharsis, it may plausibly scientifically pass as a causal-effect development. Corruption and social change in Nigeria are symptoms of larger social disconnection introduced by colonialism and continually strengthen by the new-order (globalization). Being an occurrence not restrict-able to any class, the middle range theory of Robert Merton $(1968 ; 1938)$ captures the view when he assume that the society set goals-culturally desirable to all individuals, but often make unequal the attainment opportunities for achievement. His thesis underscores corruption and capitalist ideologies. In essence people want to get money, good houses, job, education, wealth and high social status. However, better understood is the fact that the means is not always there therefore, people often lose sight of honesty, integrity and good name to subvert system, rob, steal and kill to get material benefit without considering its consequences. This is what Merton refers to as innovative or revolutionary approach to social realities that occur in human societies.

Corruption and social change are causative of economic forces. Stigliz (2001) suggest that poverty is a 'combination of circumstances'. It centres on laissez-faire-capitalism and peripheral trade that does not protect local industry and harnessing local resources but foreign ownership of means and control of modern venture. Social development in Nigeria therefore represents 'change' that characterizes lawlessness and nepotism. 
While Nigeria have the highest human density in Africa, it represent the most predominantly economically and politically corrupt, and one of the poorest and undeveloped in the world (World Bank, 2008; World Bank \& FOS, 2001).

Cross-cultural analysis of corruption and social change tend to be guilty of a canard of universalism. Dissimilarity in policies, class structure, history, nature of the ruling elites and pattern of integration into global system arrangement, as well as cultural variations go a long way to influence change and the development of particular social orientations and ideology. Therefore, envisaging factors that causes corruption in Nigeria will be different from the one elsewhere in the world.

Poverty, unemployment and supplanted cultural values have distorted social identity in Nigerian society. Poor governance and the incorporation of Nigeria into international capitalist system are factors and processes that resulted in structural change which seem to sustain corruption in the country today. Scholars believe such social condition is dependent on the ruling elite or class structure Pareto (1906), Machiavelli (1469-1527) others Luhmann (1995), Giddens (1979) submit it is the global economy structure that dictates the pace of change while others agree it is a function of early developmental stage hence the social challenges (UN Habitat, 2008; Smith \& Timberlake, 1993; Datta, 1990; Kasarda \& Crenshaw, 1991). These assumptions seem to oversight the looming fundamental issues that colonialism consciously created in its wake. Nigeria appears to have become a dichotomous legacy of a progressive ideology of the West to the regression of her culture and identity. Courageous nationalists have in time past, emerged to trigger positive and genuine changes germane to the recovery of her cultural identity as a people, but the surge of lack of socio-political apathy and corruption often leave the struggle in dead allies and more problem mounting in its wake. Wither the withering family and ethnic values of yesteryear

\section{References}

Achebe, C. (1958). Thing Fall Apart.Heinemann. Ibadan.

Achebe, C. (1984). The Trouble with Nigeria.Heinemann. Ibadan

African Development Bank (2014). Nigerian Economic Outlook.available at http://www.afdb.org/en/countries/westafrica/nigeria/nigeria-economic-outlook/

Afrobarameter,.(2013). Citizens Perception on Elections and the Effect of Corruption on Fuel Subsidy Removal in Nigeria.available at http://www.afrobarometer.org/files/documents/press_release/nig_r5_pr1.pdf

Ahmed, S. \&Ullah, G. (2014). Global Corruption Hoax: Politicization of the Concept of Corruption and the Issues of Corruption Measurement Indices. Journal of Economics and Sustainable Development, Vol. 5.No.7.

Akanbi, M.M. (2007). "Corruption and the Challenge of Governance in Nigeria." In Olurode, L and Anifowose, R. (eds.) Rich but Poor: Corruption and Governance in Nigeria. Faculty of Social Science, University of Lagos.

Akanle, O. (2009a). Caught in the Morass: Road Map for Civil Society Organization in "Democratic" Nigeria.In Olutayo, O.A., Ogundiya, I.A., and Amzat, J. eds. State and Civil Society Relations in Nigeria. Nigeria: Hope Publication Limited.

Akanle, O. (2012). The Ligaments of Culture and Development in Nigeria.International Journal of Applied Sociology.Vol. 2.No.3.

Anthony, G. (1979). Central Problems in Social Theory: Action, Structure and Contradiction in Social Analysis. Berkeley: University of California Press.

Asogwa, N.U. (2008). "Money Consciousness and Economic Materialism in Nigeria: Reflections on a Peoples Values." In O. Anichebe (ed.) Logic, Philosophy and Human Existence.Afro-OrbisPubilcation.

Babawale, T. \&Onuah, B. (2007)."The State, Corruption and the Challenge of Good Governance in Nigeria." In Olurode, L. and Anifowose, R. (eds.) Rich but Poor: Corruption and Good Governance in Nigeria. Faculty of Social Science: Univeristy of Lagos.

Bayly, C.A. (2008).The Birth of the Modern World 1780-1914. Global Connection and Comparisons. Malden, MA: Blackwell Publishing.

Chuta, S.C. (2008). Corruption in Nigeria. Afro-OrbisPubilcation

Datta, S. (1990).Third World Urbanization: Reappraisals and New Perspectives. Stockholms: HSFR.

Egbeke, A. (2000). "Crisis of Value: A Bane of National Development in African Family." In S.C. Chuta (ed.) African Humanities. Cape Publishers International Limited.

Ekong, E.E. (2003). Rural Sociology: An Introduction and Analysis of Rural Nigeria. Dove Educational Publishers. Nigeria

Erdmann, G. \& Engel, U. (2006). Neopatrimonialism Reconsidered: Critical Review and Elaboration of an Elusive Concept. Commonwealth and Comparative Politics.Vol 45.No.1. 
Ezeanya, P.O. (2009). "Socio-Moral Implication of Globalization to the African Family." In O. Anichebe (ed.) Issues in Nigeria Peoples and Culture $9^{\text {th }}$ ed. Afro Orbis Publication Limited.

Falola, T. \& Heaton, M.M. (2008).A History of Nigeria.Cambridge University Press.

Freedom House. (2012). Countries at the Crossroads: Nigeria. Available at http://www.freedomhouse.org/report/countries-crossroads/2012/nigeria\#.VCFhFvmSwg0

Fritz, V. \&Menocal, A.R. (2007). Developmental Sates in the New Millenium: Concepts and Challenges for a New Aid Agenda. Development Policy Review, Vol. 25. No.5.

Garba, Abdul-Ganiyu.(2003). "The Past, Present and Possible Features of Africa." In Garba, Abdul-Rasaq (ed.) Development Thought, Policy Advice and Economic Development in Africa in the $20^{\text {th }}$ Century: Lessons for the $21^{\text {st }}$ Century. Ibadan: Ibadan University Press.

Global Witness.(2012). Global Witness Submission to International Development Select Committee Inquiry on Tax and Development. Available at http://www.globalwitness.org/sites/default/files/library/Global\%20Witness\%20submission\%20to20IDC\%20Ta x\%20Inquiry\%206\%Feb\%202012.pdf

Gottdiener, M. \& Hutchinson, R. (2006).The New Urban Sociology.Third Edition. Boulder, Colorado: Westview Press Heidenheimer A.J. (1978). Major Reforms of the Swedish Education System 1950-1975. World Bank.

Chuta, S.C. (2004). Corruption in Nigeria. Afro-Orbis Publishing Co., Nsukka.

Jencks, C. (1996). “The City Never Sleeps.” New Statesman, 125 (4290) June.

Jigbale, E. (2016). Corruption, Religion and Societal Values. available at https://www.vanguardngr.com/2016/06/corruption-religion-societal-values/

Kasarda, J. \& Crenshaw, W. (1991). "Third World Urbanization: Dimesions, Theories and Determinants," Annual Review of Sociology, Vol. 17,467-501

Kathleen, M. (2003). Corruption: A Critical Obstacle for Social Development. Remarks to the High-Level Meeting on Poverty, Equity, and Social Inclusion Fourth Plenary Session. Isla Margarita, Venezuela, October 10.

Ko, K. \&samajdar, A. (2010). Evaluation of International Corruption Indexes: Should We Believe Them or Not? The Social Science Journal, Vol. 47. 508-540.

Lipset, M. \& Lenz, G.S. (2000).“Corruption, Culture and Markets.” In Culture Matters, Lawrence, E., Harrison and Samuel, P. Huntington (eds.). New York Basic Books.

Longe, J.S. (2015). Public Perception on Corruption and Cybercrime: Implications on Socio-Cultural Development in Nigeria. Journal of Social and Management Sciences, Vol. No.1

Luhmann,, N. (1995). Social Systems.(John Bednarz, Jr. Trans.). Stanford, CA: Stanford University Press.

Machiavelli, N. (1532/1979).The Prince. Middlesex, England: Penguin.

Madukwe, C.I. \&Madukwe, H.N. (2010). African Value System and the Impact of Westernization: A Critical Analysis. International Journal of Research in Arts and Social Sciences, Vol. 2.264-274.

Ndubueze, P. N. (2011). Emerging and Continuing Trends of Deviance Subculture and Identities among Undergraduates in Nigerian Tertiary Institutions. International Journal of Health and Social Inquiry, 1(1).

Merton, R. (1938). “Social Structure and Anomie.”American Sociological Review, Vol. 3.No.82.

Merton, R. (1968). Social Theory and Social Structure. Enlarged ed. New York: Free Press.

Odinye, I. \&Odinye, I. (2012).Western Influence on Chinese and Nigerian Cultures. Ogirisi: A New Journal of African Studies, Vol. 9. No.

Okereke, O.P. (2015). Corruption and Development in Nigeria: A Critical Re-Examination. Journal of Research on Humanities and Social Sciences, Vol. 1.No.18.

Okojie, J. (2012). Corruption had Assume a Worrisome Level. availablehttp://www.vanguard.com

Okolocha, C.F. (2009). Modern Urbanism and Social Disorganization in Africa.Nigerian Journal of Economics and Social Studies, Vol. 51.No.2.

Okolocha, C.F., Longe, J.S. \&Alenkhe, O.A. (2013). Corruption in Nigeria: Causes and Consequence to Social Development. Benin Journal of Social Science, Vol. 21.No.2.

Olutayo, A.O. \&Akanle, O. (2007).Modernity, McDonaldisation and Family Values in Nigeria.The Nigerian Journal of Sociology and Anthropology, Vol.5.No.46.

Olutayo, A.O. \&Omobowale, A.O. (2005).Globalization, Democracy and the New Partnership for African Development (NEPAD).African Journal of the Psychological Studies of Social Issues.Vol.8. No.2.

Omonijo, D. O., Uche, O. O., Rotimi, O. A., \& Nwadiolor, K. (2013). Social Analysis of Moral Malpractice Challenging Education Sector in Nigeria. SCIENCEDOMAIN International 4(7), 965-986.

Otite, O. \&Ogionwo, W. (2006).An Introduction to Sociological Studies. Nigeria: Heinemann Educational Books.

Otite, O. (2002). Managing Nigeria's Ethnic Pluralism in Democratic Environment.Cats Publishers.

Pareto, V. (1906/1971).Manual of Political Economy. New York: Augustus Kelly. 
Pratten, D. (2007). The Man Leopard Murders: History and Society in Colonial Nigeria. London: Edinburgh University Press for International African Institute.

Smith, D. \& Timberlake, M. (1993). "World Cities: A Political Economy/ Global Network Approach.” In Hutchinson, R. (ed.) Urban Theory in Transition. Greenwich, Connecticut: J.A.I.

Smith, D.J. (2001). Kinship and Corruption in Contemporary Nigeria.Ethos, Vol. 66.No.3.

Smith, D.J. (2010). A Culture of Corruption: Everyday Deception and Popular Discontent in Nigeria. Princeton University Press.

Ibhawoh, B. (2002). Stronger than the Maxim Gun Law, Human Rights and British Colonial Hegemony in Nigeria. Africa, 72(1), 55-83.

Iwara, I. E. (2015). Cultural hegemony and Africas Development Process. African Journal of Political Science and International Relations, 9(4), 120-130.

Stigliz, J.E. (2017). Globalization and Its Discontents Revisited: Anti-Globalization in the Era of Trump. W.W. Norton.

The Book of Second Peter 1:4. The King James Version of the Bible (2008).Rhapsody of Reality Devotional Study Bible.LoveWorld Publishing, Believers' LoveWorld Inc.

Transparency International.(2014). Corruption Perceptions Index.available at http://www.transparency.org

UN Habitat. (2008). The State of African Cities. A Framework for Addressing Urban Challenges in Africa. Nairobi: UN Habitat.

Vago, S. (1999).Social Change.Forth Edition. Prentice-Hall, Inc.

Vaughan, O. (2005). The Crisis of the Nigerian State in the Global Era.In O.Vaughan, M. Wright and C. Small. (eds.) Globalization and Marginalization. Ibadan: Sefer Books Ltd.

Victor, D. (2014). "Leadership and the Nigerian Economy" Sage Open, Vol. 4.No.1.

World Bank (2001).Regional Report- African Region.Spring.

World Bank and FOS (2008).Poverty and Welfare in Nigeria.Poverty Handbook of Federal Office of Statistic and National Planning Commission.

World Bank.(2007). Enterprise Survey.availablehttp://www.enterprisesurveys.org/data/exploreeconomies/2007/nigeria

Yakubu, B. (2014). How Western Culture Erodes Values among Nigerian Youths. Daily Trust.available at https://www.dailytrust.com.ng/daily/home-front/31162-how-western-culture-erodes-values-among-nigerianyouths 